\title{
The Co-mentoring Project: Overview and Outcomes
}

\author{
Renée A. Zucchero, PhD \\ Assistant Professor, Department of Psychology \\ Xavier University
}

The Co-mentoring Project matched developmental psychology students with older adult volunteers for an intergenerational learning experience. Students conducted a biopsychosocial life review to increase understanding of older adult development and the continuity in lifespan development. Each student developed a summary paper containing the older adult's life history, a developmental analysis, and personal reflection. A project description, including the scholarship of teaching and learning, and an overview of its outcomes are presented. The project goal was accomplished; students positively evaluated learning outcomes and displayed a significant increase in knowledge about older adults and aging. Implications for college instructors are discussed.

The scholarship of teaching and learning (SoTL) involves careful planning and continuous examination (Boyer, 1990), and the systematic investigation of questions related to student learning with the purpose of advancing general practice (Hutchings \& Shulman, 1999). Scholars may ask, "What works?" (Hutchings, 2000; Nummedal, Benson, \& Chew, 2002) "What are the conditions under which learning occurs?" "What does learning look like?" or "How can I deepen it?" (Hutchings \& Shulman, 1999). More specific questions, such as how, when, where, and why students learn and how faculty can create optimal learning opportunities are also posed in the SoTL (Georgia Southern University, Center for Excellence in Teaching, n.d.). The questions raised are discipline based (Hutchings, 2000; McKinney, n.d.) and arise from "the character of the field" (Hutchings, 2000, p. 9). The issue addressed in the current article, "How can we best educate undergraduate students about the process of aging and older adults?" is consistent with the aforementioned inquiries into the SoTL.

Experiential learning is a common pedagogy, selected as it is believed to be superior to traditional teaching methods. Experiential education activities involve direct experience with the topics being studied (Cantor, 1995; Moore, 2000). Hands-on, active

Experiential learning is a common pedagogy, selected as it is believed to be superior to traditional teaching methods.

Experiential education activities involve direct experience with the topics being studied. learning experiences are believed to facilitate a more accurate understanding of the process of aging and a change in the negative attitudes students frequently hold about older adults (Bringle \& Kremer, 1993). As experiential learners, students are actively engaged in discovering and experimenting with knowledge, rather than being passive recipients of information (Stevens \& Richards, 1992).

Two commonly employed techniques are intergenerational experiential learning and service-learning. Intergenerational learning experiences include meaningful interaction (O'Hanlon \& Brookover, 2002), "constructive" exchange, and mutual sharing between the generations (Hamon \& Koch, 1993). Ageism may be best combated through relationships that allow students "to experience the meaning of aging through direct, dialogical contact with elders" (McGowan \& Blankenship, 1994, p. 603). Service-learning is one type of experiential education that includes intentional learning goals and active reflection on learning (National Society for Experiential Education, 1994, as cited by Furco, 1996). The amount and quality of reflection has been recognized as a predictor of service-learning outcomes (Eyler \& Giles, 1999). Additionally, service-learning involves integration of service into the academic curriculum (Furco, 1996; Waterman, 1997, as cited in Blieszner \& Artale, 2001) and extending learning beyond the classroom (Waterman, 1997, as cited in 
Blieszner \& Artale, 2001). Application, linking classroom and community experiences, has consistently been associated with better academic learning outcomes (Eyler \& Giles, 1999).

Several domains in which students benefit from service-learning have been identified: a deeper understanding of the subject matter (Eyler \& Giles, 1999); the ability to apply material learned in class (Cavanaugh, 2001; Eyler \& Giles, 1999); increased personal and interpersonal development (Eyler \& Giles, 1999); and an increase in student selfunderstanding (Cavanaugh, 2001). Moore (2000) suggested that experiential learning and service-learning assist in developing practical knowledge and skills. Likewise, service-learning activities can have an impact on "perspective

Several domains in which students benefit from service-learning have been identified: a deeper understanding of the subject matter; the ability to apply material learned in class; increased personal and interpersonal development; and an increase in student selfunderstanding. transformation" (Eyler \& Giles, 1999).

Outcomes of intergenerational experiential learning have been measured by changes in student attitudes or level of knowledge about older adults, or by comparing course grades of students who engage in service-learning to grades of those who do not. Qualitatively, outcomes have been assessed by review of student journal entries or writing assignments. Usually, the capstone has been a summary paper, reflective assignment, or an in-class presentation.

Studies regarding intergenerational learning between undergraduate students and older adults have typically occurred in the context of older-adult focused courses: gerontology (Brown \& Roodin, 2001; Doorfman, Murty, Ingram, \& Evans, 2002; Hamon \& Koch, 1993; Hanks \& Icenogle, 2001; Karasik, 2002; O'Hanlon \& Brookover, 2002; Purk \& Lague, n.d.) or the psychology of aging (Anguillo, Whitbourne, \& Powers, 1996; Evans, 1981; Whitbourne \& Collins, 1999; Whitbourne, Collins, \& Skultety, 2001). Only one study has described an intergenerational learning experience in the context of a lifespan development course (Neysmith-Roy \& Kleisinger, 1997).

Thus, intergenerational learning may take the form of experiential education or service-learning and typically occurs in the context of a course about older adulthood. The rationale for these pedagogies is the potential for improved learning outcomes in several domains, consistent with the deepening of student learning (Hutchings \& Shulman, 1999) and creation of optimal learning outcomes (Georgia Southern University Center for Excellence in Teaching, n.d.) found in the SoTL. Key ingredients of experiential learning include active, direct, and meaningful contact with older adults, about which students reflect and which is integrated into the in-class experience.

For the Co-mentoring Project, students in a lifespan developmental psychology course were paired with older adult volunteers for an intergenerational learning experience. The goal was to increase student understanding of older adult development and the continuity that exists in development across the lifespan. Several research questions were systematically investigated. First, was the project goal achieved? Similarly, did students become more knowledgeable about older adults and aging? Did the project facilitate student learning about lifespan development, the life of an older adult, and the application of developmental theory and integration of the different stages of life to a real person's life? Finally, what common themes did students report about their project experiences? These questions are consistent with those commonly posed in the SoTL. 


\section{Participants}

The Co-mentoring Project occurred during three consecutive semesters beginning in the fall of 2005 and was deemed exempt from IRB oversight. Students in developmental psychology at a small, Midwestern, private, Catholic university were strongly encouraged to participate. They were offered the option to complete an alternate assignment; however, all chose to participate $(N=70)$. Developmental Psychology is required for psychology majors and minors, and for occupational therapy majors. Students in related disciplines also enroll. Students were overwhelmingly traditionally-aged undergraduates. More specific information regarding student participants is presented in Table 1.

Table 1: Characteristics of Student Participants

\begin{tabular}{|c|c|c|c|}
\hline \multicolumn{2}{|c|}{ Characteristic } & $n$ & Percentage \\
\hline \multirow[t]{2}{*}{ Gender } & Female & 52 & 74 \\
\hline & Male & 18 & 26 \\
\hline \multirow{5}{*}{ Class Standing } & Freshman & 9 & 13 \\
\hline & Sophomore & 27 & 39 \\
\hline & Junior & 23 & 33 \\
\hline & Senior & 8 & 11 \\
\hline & Graduate & 3 & 4 \\
\hline \multirow[t]{4}{*}{ Ethnicity } & Caucasian & 60 & 86 \\
\hline & African American & 7 & 10 \\
\hline & Hispanic & 1 & 1 \\
\hline & Asian & 2 & 3 \\
\hline \multirow[t]{4}{*}{ Major/Minor } & Psychology & 47 & 67 \\
\hline & Occupational Therapy & 9 & 13 \\
\hline & $\begin{array}{l}\text { Related Disciplines (i.e., } \\
\text { Nursing, Education, } \\
\text { Biology) }\end{array}$ & 7 & 10 \\
\hline & $\begin{array}{l}\text { Other (i.e., } \\
\text { Communication Arts, } \\
\text { Undecided, Liberal Arts) }\end{array}$ & 7 & 10 \\
\hline
\end{tabular}

The instructor recruited older adult co-mentors primarily from the independent living sections of two local private, continuous care retirement communities. A total of 74 volunteers participated, after providing written consent. Volunteers were typically over the age of 70 years, Caucasian, Christian, and of a middle or upper level socioeconomic status (SES). Co-mentors were physically wellenough to participate, which required attendance of meetings at the university. Additional information about the older adult participants is presented in Table 2.

Table 2: Characteristics of Older Adult Participants

\begin{tabular}{|l|l|c|c|}
\hline \multicolumn{2}{|c|}{ Characteristic } & $n$ & Percentage \\
\hline \multirow{2}{*}{ Gender } & Female & 48 & 65 \\
\cline { 2 - 4 } & Male & 26 & 35 \\
\hline $\begin{array}{l}\text { Number of } \\
\text { Pemesters }\end{array}$ & One Semester & 55 & 74 \\
\cline { 2 - 4 } & Two Semesters & 13 & 18 \\
\cline { 2 - 4 } Residential Setting & Three Semesters & 6 & 8 \\
\hline & $\begin{array}{l}\text { Retirement } \\
\text { Community }\end{array}$ & 68 & 92 \\
\cline { 2 - 4 } & In the Community & 6 & 8 \\
\hline
\end{tabular}




\section{Procedure}

Students were briefed about the project at the beginning of the course and were presented with an assignment sheet that included the rationale, requirements, and grading criteria for the project, as recommended by Hamon and Koch (1993). A 50-minute interview-skills lecture was also provided, during which students began to develop a list of questions for the interviews, similar to previous studies (Neysmith-Roy \& Kleisinger, 1997; O'Hanlon \& Brookover, 2002; Walton, 1988). Thus, others' work serves as a foundation for the project, which is essential to the SoTL (Richin, 2001; Richlin \& Cox, 1991).

Students and their partners were generally matched in a random manner and initially met at a group meeting within the first month of the semester. Thereafter, the dyads met at least twice, in person, to conduct a comprehensive, biopsychosocial life review via a student-lead, semi-structured interview. The length and content of meetings was determined by the dyads.

Students completed written reports of the life reviews, including developmental analyses of their partners' lives and personal reflections about their experiences. For the latter, students were instructed to discuss their cognitive and emotional reactions to the assignment, including what they learned intellectually and in terms of life lessons or "pearls of wisdom." Students also created a poster presentation, focused on the life history and developmental analysis. Two months after the initial group meeting, the students and older adults reconvened to share the papers and poster presentations.

\section{Measures}

Students completed a shortened version of The Facts on Aging Quiz (FAQ) (Palmore, 1998) within the first three class periods and near the end of the semester. This methodology is consistent with the SoTL, which calls for a baseline assessment of student knowledge (Nummedal et al., 2002; Richlin, 2001). The FAQ is a commonly used 25-item, true-false questionnaire that assesses knowledge of the physical, social, and psychological aspects of aging and stereotypes of older adults. There are two forms of the FAQ-FAQ1 and FAQ2. This study included the first 18 items from the FAQ1 scale; the shortened scale was used to decrease administration time (see Appendix A). Palmore (1998) reported the FAQ1 is reliable and valid. The FAQ has been used with a variety of populations, including undergraduate students, graduate and medical students, and non-student populations.

Students anonymously completed a structured, 12-item evaluation after finishing the project, but before evaluative feedback about their projects was provided. Item responses used a 5-point Likert-type scale, varying from "strongly agree" to "strongly disagree." A copy of this evaluation can be found in Appendix B. The content of the students' personal reflections was analyzed for themes and aggregated to better understand their experience of the project. To increase the reliability of the interpretation of themes, the researcher, one clinical psychology graduate student, and one undergraduate psychology student analyzed the personal reflections individually and then met as a group to compare interpretations.

\section{Results}

\section{Quantitative Results}

The project evaluation had good internal consistency, as indicated by a Cronbach alpha coefficient of .79. All students completing evaluation item 1 indicated the project's purpose was achieved $(N=63)$. Results from additional evaluation items relevant to the research questions can be found in Table 3. Overall, 
most students responded favorably to these questions. Additionally, there was a statistically significant increase in the students' knowledge about older adults and aging, from pre-test (FAQ $M=13.53, S D=2.41)$ to post-test (FAQ $M=15.19, S D=$ 1.81), $t(58)=-5.31, p \leq .001$ (two-tailed), $\eta^{2}=.33$. The magnitude of the differences in the means was large.

Table 3: Responses for Student Evaluations

\begin{tabular}{|c|c|c|c|c|c|c|}
\hline \multirow[b]{2}{*}{ Question } & \multicolumn{5}{|c|}{$\begin{array}{c}\text { Responses } \\
\text { Number of responses (\% of responses) }\end{array}$} & \multirow{2}{*}{ 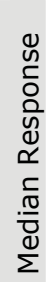 } \\
\hline & 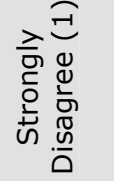 & 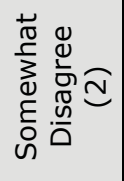 & 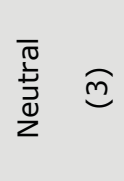 & 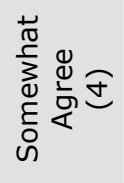 & 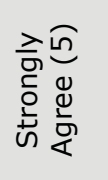 & \\
\hline $\begin{array}{l}\text { 2. This project was a helpful } \\
\text { way to learn about lifespan } \\
\text { development. }\end{array}$ & -- & $\begin{array}{c}3 \\
(5 \%)\end{array}$ & $1(2 \%)$ & $\begin{array}{c}37 \\
(58 \%)\end{array}$ & $\begin{array}{c}22 \\
(35 \%)\end{array}$ & 4 \\
\hline $\begin{array}{l}\text { 5. This project was a helpful } \\
\text { way to learn about the life of } \\
\text { an older adult. }\end{array}$ & -- & $\begin{array}{c}1 \\
(2 \%)\end{array}$ & -- & $\begin{array}{c}23 \\
(37 \%)\end{array}$ & $\begin{array}{c}39 \\
(62 \%)\end{array}$ & 5 \\
\hline $\begin{array}{l}\text { 7. This project was not a } \\
\text { helpful way to learn about the } \\
\text { process of aging. }\end{array}$ & $\begin{array}{c}28 \\
(44 \%)\end{array}$ & $\begin{array}{c}29 \\
(46 \%)\end{array}$ & $1(2 \%)$ & $\begin{array}{c}5 \\
(8 \%)\end{array}$ & -- & 2 \\
\hline $\begin{array}{l}\text { 12. As a result of this project, } \\
\text { I better understand how to } \\
\text { apply developmental theory } \\
\text { and integrate the different } \\
\text { stages of life to a real person's } \\
\text { life. }\end{array}$ & -- & $\begin{array}{c}6 \\
(10 \%)\end{array}$ & $1(2 \%)$ & $\begin{array}{c}39 \\
(62 \%)\end{array}$ & $\begin{array}{c}17 \\
(27 \%)\end{array}$ & 4 \\
\hline
\end{tabular}

\section{Common Themes Reported in Students' Personal Reflections}

Sixty personal reflections were available for review. Fourteen personal reflections were available for the fall 2005 semester, 23 reflections for the spring 2006 semester, and 23 for the fall 2006 semester. Many students during the first semester did not include a personal reflection, resulting in fewer available reflections. An open coding qualitative analysis (Strauss \& Corbin, 1993) revealed numerous common themes; the six most common are presented in Table 4. A more detailed presentation of this qualitative analysis is available elsewhere (Zucchero, in preparation). 
Table 4: Summary Table of Most Common Qualitative Themes from Personal Reflections

\begin{tabular}{|l|c|c|c|c|}
\hline \multirow{2}{*}{ Themes } & \multicolumn{3}{|c|}{$\begin{array}{c}\text { Number of Occurrences } \\
\text { (\% of Occurrences) per Semester }\end{array}$} & \multirow{2}{*}{ Total } \\
\cline { 2 - 4 } & Fall 2005 & Spring 2006 & Fall 2006 & \\
\hline Admiration & $8(57 \%)$ & $18(78 \%)$ & $8(35 \%)$ & $34(57 \%)$ \\
\hline Inspiration & $8(57 \%)$ & $14(61 \%)$ & $12(52 \%)$ & $34(57 \%)$ \\
\hline Good Project & $9(64 \%)$ & $13(54 \%)$ & $11(48 \%)$ & $33(55 \%)$ \\
\hline $\begin{array}{l}\text { Advice/Learned about life/ } \\
\text { Significant influence }\end{array}$ & $7(50 \%)$ & $6(26 \%)$ & $14(61 \%)$ & $27(45 \%)$ \\
\hline $\begin{array}{l}\text { Positive Quality of the } \\
\text { Older Adult }\end{array}$ & $2(14 \%)$ & $8(35 \%)$ & $15(65 \%)$ & $25(42 \%)$ \\
\hline Introspection & $6(43 \%)$ & $8(35 \%)$ & $10(43 \%)$ & $24(40 \%)$ \\
\hline \multicolumn{2}{|l|}{\begin{tabular}{l} 
Number of Personal Reflection \\
\hline
\end{tabular}}
\end{tabular}

\section{Discussion}

According to students' self-report, the overall goal of the Co-mentoring Project was achieved. An overwhelming majority of students disagreed with an evaluation item indicating the project was not a helpful way to learn about aging. Similarly, most students agreed the project was helpful in learning about lifespan development. Thus, in agreement with previous studies (Blieszner \& Artale, 2001; Whitbourne et al., 2001), most student self-reports indicated the Co-mentoring Project assisted in increasing their understanding of aging and lifespan development. Students also displayed a significant increase in knowledge about aging and stereotypes about older adults, which is consistent with prior research (Angiullo et al., 1996).

Application of course information is a key facet of this project which has been identified as a benefit of service-learning (Cavanaugh, 2001; Eyler \& Giles, 1999). Most students indicated that their understanding of how to apply theory to the life of a unique individual improved, and students' personal reflections were indicative of this. For example, a student wrote, "... I did not just memorize this information for a test, but I really learned it. This information will stick in my head because I applied the information to [my partner's] life." Enduring learning has been identified as a goal of the Carnegie Academy for the Scholarship of Teaching and Learning (CASTL) (Hutchings, 2000).

Eyler and Giles (1999) emphasized the integration of service-learning into the course. The students' project-related experiences, including their partners' life histories, experiences, and advice were frequently incorporated into class discussions. Students frequently used their co-mentoring experience as a basis for discussion about older adulthood-experience that may not have been available to them without the project, due to the distant relationships many young people often have with older adults. Thus, the experiences associated with the project are carefully integrated into the course.

Eyler and Giles (1999) described the importance of reflection on servicelearning outcomes. Students completed a personal reflection, including their cognitive and emotional responses. Introspection was spontaneously reported by 40 percent of the participants. This is congruent with Cavanaugh's (2001) belief that college education should increase self-understanding. Nearly half of students reported they received advice from their partners, learned about life, or that their partner had a significant influence on their lives. One student wrote, "I didn't only learn more about developmental theories and processes from interviewing [my comentor], I learned about life." This is consistent with the idea that students may have developed personally as a result of the project (Eyler \& Giles, 1999).

Some students may have experienced "perspective transformation" (Eyler \& Giles, 1999). For example, more than half of participants described being inspired 
by their partner, and over half indicated they admired their co-mentor. Over 40 percent of students reported a positive quality of their co-mentor. Often, this statement was made in the context of the students changing their perceptions about what older adults are "supposed to be like."

Overall, 55 percent of students described the Co-mentoring Project as a "good project" in their personal reflections. In reviewing the context of these statements, many students indicated they enjoyed spending time with their partners. Other students indicated the project forced them to apply what they had learned in class. Still others reported they learned about life as a result of the meetings with their partners. Thus, the reasons why students had a positive project experience varied.

The SoTL entails systematic inquiry into student learning (Hutchings \& Shulman, 1999). The Co-mentoring Project regularly assessed student learning by using a pre-and postassessment of knowledge of aging and older adults. In addition, students evaluated the project at the end of the semester. Student personal reflections were reviewed for themes by a team of three, and those themes were aggregated to understand the commonalities of the student experience. This multidimensional assessment strategy is consistent with a "higher standard" of scholarship and a more comprehensive review strategy (Richlin \& Cox, 1991) required by the SoTL. Moreover, it builds upon the work of others (Richlin, 2001; Richlin \& Cox, 1991) by using three capstone experiences (i.e., life review paper, personal reflection, and poster presentation).

Nummedal et al. (2002) indicated the experimental method is not currently an appropriate "approach to inquiry" for the SoTL in the field of psychology. The limitations of this study are congruent with this statement. No control group was available. Therefore, it is not possible to attribute the students' increased knowledge about older adulthood solely to their participation in the project. Also, several outcomes are based upon the students' self-report, with the modified FAQ serving as an objective outcome measure. Hence, it is possible that demand characteristics or social desirability may have skewed some results. Finally, most of the older adult volunteers were healthy, which may have positively biased the students' perceptions of older adults.

This study has implications for college teachers from a variety of disciplines. This study shows that a project focused on older adults and aging can successfully be integrated into a lifespan development course. Therefore, similar projects could reach a broader student base, including those who might not choose to enroll in an elective specific to older adults. Application of theory, as required in this project, may make course content more meaningful to students. Thus, this assignment is appropriate for courses that are based in theory, such as psychology or sociology courses.

Students who are enrolled in courses of study leading to helping professions (i.e., nursing, physical therapy, premedical studies) would benefit from this assignment, since the world and American populations are aging. While it is likely that these students will be serving a large number of older adults, they may have limited exposure to this growing population. Moreover, 33 percent of the student participants were enrolled in courses of study other than psychology, including occupational therapy, education, and liberal arts.

Also, students' developmental analyses assessed the impact of historical events on their partners' lives (i.e., history-graded, normative life events). For many students, distant historical events (i.e., the Great Depression, World War II) became more personally meaningful and relevant. Consequently, this project may be complementary for history courses. Communication arts students may gain from such an assignment, as a study of intergroup communication processes. In addition, the project's methodology could be modified for use with other underserved populations, such as ethnic minorities or persons of lower socioeconomic status.

InSight: A Journal of Scholarly Teaching 
Several statements about the student project experience can be made. All students reported the project's goal was achieved and the overwhelming majority evaluated the project's learning outcomes positively. In addition, student performance on an objective measure of knowledge about aging significantly improved. The project has several characteristics of an effective service-learning experience: reflection, integration with course content, and application/linkage of student experiences. A comment from a student's personal reflection represents an optimal learning experience: "I realize now why this is a co-mentoring project! ... We learned a lot from each other."

In conclusion, the Co-mentoring Project is an example of the scholarship of teaching and learning. The systematic investigation of the question, "How can we best educate undergraduate students about the process of aging and older adults?" is congruent with the investigation of those questions posed by scholars in this area. Specifically, the question, "What works?" is representative of those raised within the discipline of psychology (Nummedal et al., 2002). Baseline assessment is utilized regularly in the SoTL (Nummedal et al., 2002; Richlin, 2001) and this project. Moreover, the project undergoes continuous examination (Boyer, 1990) to deepen the students' experience (Hutchings \& Shulman, 1999) and create "optimal learning outcomes" (Georgia Southern University, Center for Excellence in Teaching), as demonstrated in this article.

\section{References}

Anguillo, L., Whitbourne, S.L., \& Powers, C. (1996). The effects of instruction and experience on college students' attitudes toward the elderly. Educational

Gerontology, 22, 483-495.

Blieszner, R. \& Artale, L.M. (2001). Benefits of intergenerational servicelearning to human services majors. Educational Gerontology, 27, 71-87.

Boyer, E.L. (1990). Scholarship reconsidered: Priorities of the professoriate. Princeton, NJ: Carnegie Foundation for the Advancement of Teaching.

Bringle, R.G. \& Kremer, J.F. (1993). Evaluation of an intergenerational service-learning project for undergraduates. Educational Gerontology, 19, 407-416.

Brown, L.H. \& Roodin, P.A. (2001). Service-learning in gerontology: An out-of-classroom experience. Educational Gerontology, 27, 89-103.
Cantor, J.A. (1995). Experiential learning in higher education: Linking classroom and Community (Report No. ED 404949). Washington, DC: ERIC Clearinghouse on Higher Education. Retrieved June 29, 2007, from http://eric.ed.gov/ERICDocs/ data/ericdocs2sql/content_storage_0 1/0000019b/80/6/52/f8.pdf

Cavanaugh, J.C. (2001). Learning and doing: The importance of service-learning in gerontology. Educational Gerontology, 27, 117124.

Doorfman. L.T., Murty, S., Ingram, J.G., \& Evans, R.J. (2002). Incorporating intergenerational service-learning into an introductory gerontology course. In M.J. Mellor \& J. Ivry (Eds.), Advancing gerontological social work education (pp. 219-240). Binghamton, NY: The Haworth Press, Inc.

Evans, J.D. (1981). Personal involvement projects in the psychology of aging: Some examples and an empirical assessment. Teaching of Psychology, 8, 230-233. 
Eyler, J. \& Giles, D.E. (1999). Where is the learning in service-learning? San Francisco, CA: John Wiley and Sons, Inc.

Furco, A. (1996). Service-learning: A balanced approach to experiential education. In B. Taylor (Ed.).

Expanding boundaries: Service and learning (pp. 2-6). Washington, DC: Corporation for National Service.

Georgia Southern University Center for Excellence in Teaching. What is SoTL? (n.d.). Retrieved May 15, 2008, from

http://academics.georgiasouthern.ed u/cet/sotl_info.htm

Hamon, R.R. \& Koch, D.K. (1993). The elder mentor relationship: An experiential learning tool. Educational Gerontology, 19, 147-159.

Hanks, R. S. \& Icenogle, M. (2001). Preparing for an age-diverse workforce: Intergenerational servicelearning in social gerontology and business curricula.

Educational Gerontology, 27, 49-70.

Hutchings, P. (Ed.) (2000). Opening lines: Approaches to the Scholarship of Teaching and Learning. Princeton, $\mathrm{NJ}$ : Carnegie Foundation for the Advancement of Teaching.

Hutchings, P. \& Shulman, L.S. (1999). The scholarship of teaching: New Elaborations, New

Developments. Change, 31, 10-15.

Karasik, R.J. (2002, October). So that's what it's like to be old! The impact of intergenerational servicelearning on undergraduate attitudes toward aging. Poster presented at the $55^{\text {th }}$ Annual Scientific Meeting of the Gerontological Society of America, Boston, MA.

McGowan, T.G. \& Blankenship, S. (1994). Intergenerational experience and ontological change. Educational Gerontology, 20, 589-604.
Moore, D.T. (2000). The relationship between experiential learning research and service-learning research. Michigan Journal of Community Service Learning, 7, 124-128.

Neysmith-Roy, J.M. \& Kleisinger, C.L. (1997). Using biographies of adults over 65 years of age to understand life-span developmental psychology. Teaching of Psychology, 24, 116-118.

Nummedal, S.G., Benson, J.B., \&

Chew, S. L. (2002). Disciplinary styles in the scholarship of teaching and learning: A view from psychology. In M.T. Huber \& S.P. Morreale (Eds.), Disciplinary styles in the scholarship of teaching and learning: Exploring common ground. (Report No. ED478800). Washington, DC: ERIC Clearinghouse on Higher Education. Retrieved May 14, 2008, from

http://eric.ed.gov/ERICDocs/data/eri cdocs2sql/content_storage_01/00000 19b/80/1b/3e/7f.pdf

O'Hanlon, A.M. \& Brookover. B.C. (2002). Assessing changes in attitudes about aging: Personal reflections and a standardized measure. Educational Gerontology, 28,711-725.

Palmore, E.B. (1998). The Facts on Aging Quiz ( $2^{\text {nd }}$ edition). New York, NY: Springer Publishing Company.

Purk, J.K. \& Lague, M. (n.d.). Service-Learning and qualitative research at the State University of West Georgia. Retrieved June 7, 2007, from

http://66.102.1.104/scholar?hl=en\&l $r=\& q=$ cache: MHE6Czvz90oJ:service. gt.pitt.edu/2003regional\%2520produ cts/ServiceLearning\%2520and\%2520 Qualitative\%2520Research\%2520at $\% 2520$ the $\% 2520$ State $\% 2520$ Univers ity\%2520of\%2520West\%2520Georgi a.doc+related:MHE6Czvz9OoJ:schola r.google.com/ 
Richlin, L. (2001). Scholarly teaching and the scholarship of teaching. New Directions for Teaching and Learning, 86, 57-68.

Richlin, L. \& Cox, M.D. (1991). The scholarship of pedagogy: A message from the editors. Journal on Excellence in College Teaching, 2, 18.

Stevens, P. W. \& Richards, A. (1992). Changing schools through experiential education (Report No. ED345929). Charleston, WV: ERIC Clearinghouse on Rural Education and Small Schools. Retrieved June 29, 2007, from http://eric.ed.gov/ERICDocs/data/eri cdocs2sql/content_storage_01/00000 19b/80/28/ed/c3.pdf
Strauss, A. \& Corbin, J. (1990).

Basics of qualitative research:

Grounded theory procedures and techniques. Newbury Park, CA: Sage Publications.

Walton, M.D. (1988). Interviewing across the life span: A project for adult development course. Teaching of Psychology, 15, 198-200.

Whitbourne, S.K. \& Collins, K. (1999). Employing interactive learning methods in a course on the psychology of aging. Teaching of Psychology, 26, 48-49.

Whitbourne, S.K., Collins, K.J., \& Skultety, K.M. (2001). Formative reflections on service-learning in a course on the psychology of aging. Educational Gerontology, 27, 105115.

Zucchero, R.A. (2008). Inspiring and Admiring: Qualitative Outcomes of the Co-mentoring Project. Manuscript in preparation.

Renée Zucchero, PhD, is an Assistant Professor of Psychology at Xavier University in Cincinnati, Ohio. Her teaching responsibilities include undergraduate psychology and graduate geropsychology courses. Dr. Zucchero's research interests include pedagogy in undergraduate psychology courses and the mental health of women who experience substance use disorders. 


\section{Appendix A: The Myths of Aging Quiz}

True or False

1) The majority of old people (age 65 and older) are senile (have defective memory, are disoriented, or demented).

2) The five senses (sight, hearing, taste, smell, and touch) all tend to weaken in old age.

3) The majority of old people have no interest in, nor capacity for, sexual relations.

4) Lung vital capacity tends to decline in old age.

5) The majority of old people feel miserable most of the time.

6) Physical strength tends to decline in old age.

7) At least one-tenth of the aged are living in long-stay institutions (such as nursing homes, mental hospitals, and homes for the aged).

8) Aged drivers have fewer accidents per driver than those under age 65.

9) Older workers usually cannot work as effectively as younger workers.

10) Over three-fourths of the aged are healthy enough to carry out their normal activities.

11) The majority of old people are unable to adapt to change.

12) Old people usually take longer to learn something new.

13) It is almost impossible for the average old person to learn something new.

14) Older people tend to react more slowly than do younger people.

15) In general, old people tend to be pretty much alike.

16) The majority of old people say they are seldom bored.

17) The majority of old people are socially isolated.

18) Older workers have fewer accidents than younger workers.

\section{Appendix B: Co-mentoring Project Student Evaluation Form}

To evaluate the usefulness of this project and assist in improving it for future students, please complete this evaluation form. Rate your agreement or disagreement on questions 2 through 12 from strongly disagree (1) to strongly agree (5). Please be honest in your responses. Additional comments or suggestions are encouraged and should be included on the back of this page.

1) As indicated on the assignment form for the co-mentoring project, the purpose of the project was, "To facilitate an increase in students' understanding of the development of an older adult and the continuity that exists in development from earlier periods in the lifespan." Was this goal accomplished?

2) This project was a helpful way to learn about lifespan development.

3) This project was not intellectually challenging.

4) The interview skills lecture did not help me in preparing for the meetings with my partner.

5) This project was a helpful way to learn about the life of an older adult.

6) I feel more comfortable interacting with older adults than I did before I began this project.

7) This project was not a helpful way to learn about the process of aging.

8) I feel more comfortable in the interview situation than I did before I began this project.

9) This project was not worth the time commitment.

10) I enjoyed this project.

11) The poster presentation assisted me in developing a sense of closure for this project.

12) As a result of this project, I better understand how to apply developmental theory and integrate the different stages of life to a real person's life.

InSight: A Journal of Scholarly Teaching 